\title{
Bois et Forêts des Tropiques évolue en partenariat avec la recherche au Sud
}

Depuis fin 2018, le fonctionnement de la revue Bois et Forêts des Tropiques a évolué.

En remplacement de Jacques Tassin, Jean-François Trébuchon a pris la suite des opérations en tant que rédacteur en chef et coordinateur éditorial.

Une équipe de rédaction a été constituée, incluant six rédacteurs scientifiques : Kévin Candelier, Antoine Galiana, Laurent Gazull, Valéry Gond, Jean Gérard et Jacques Tassin. Leur mission consiste à examiner le fond scientifique des manuscrits soumis, à piloter leur évaluation en doubleaveugle avec l'aide de relecteurs internationaux du Nord et du Sud, et à accompagner les auteurs dans la rédaction finale lorsque l'article est retenu comme publiable.

Le processus d'évaluation des manuscrits s'articule donc en trois temps : (i) avis du comité de rédaction sur la recevabilité du dossier de soumission vis-à-vis de la ligne éditoriale et de la note aux auteurs, (ii) pilotage de l'évaluation, de manière constructive et bienveillante, conduite en double-aveugle par les pairs, et (iii) vérification de la prise en compte des recommandations des pairs et accompagnement à la rédaction avant mise en édition et publication.

Fin 2019, le Comité éditorial a été renouvelé. II rassemble une trentaine de chercheurs internationaux, référents de renom, intervenant dans les zones tropicales et méditerranéennes, et affiliés à des universités ou des centres de recherche internationaux. Une nouvelle fois, ce comité associe des chercheurs du Nord et du Sud, jeunes ou confirmés, selon une parité du genre et un équilibre des continents. Leur engagement est de trois années et court de 2020 à 2022. Leur mission est (i) de veiller à la qualité du contenu de la revue, en lien avec les évolutions thématiques des recherches sur l'environnement de la forêt, de l'arbre et du bois, (ii) d'assurer ponctuellement le rôle de relecteur ou de suggérer d'autres relecteurs, et (iii) bien entendu de proposer des manuscrits, en tant que co-auteur ou simple « rabatteur».

Pour le respect des exigences éthiques et déontologiques inhérentes aux pratiques de recherche, la revue s'est dotée d'un logiciel de reconnaissance et d'analyse de plagiat et d'auto-plagiat. L'outil épaule l'équipe éditoriale pour émettre un premier avis sur le manuscrit.

Figures 1.

\section{Jean-François TRÉBUCHON}

Rédacteur en chef et coordinateur éditorial
Afin de favoriser le libre accès aux publications, Bois et Forêts des Tropiques a substitué la licence CC-BY à la licence Creative Commons, offrant ainsi une grande liberté dans la réutilisation des manuscrits publiés. La préservation du droit d'auteur et du copyright, dans le respect des auteurs et de la revue, n'en est pas moins garantie.

Pour faciliter l'accès et le repérage pour les auteurs et les lecteurs, Bois et Forêts des Tropiques a également fait évoluer le logiciel gérant le site web et la soumission d'articles en ligne, tout en maintenant son référencement dans les bases de données bibliographiques internationales.

Enfin, notre revue reste gratuite, en accès libre et soutenue financièrement par le Cirad, conformément au mandat de partenariat porté par l'institution, au service de la publication de travaux de recherche assurés dans le domaine des sciences forestières, en soutien et en coopération avec la recherche au Sud. Publiée en français ou en anglais, elle demeure un tremplin pour les jeunes chercheurs et les chercheurs chevronnés œuvrant dans l'univers de la recherche appliquée.

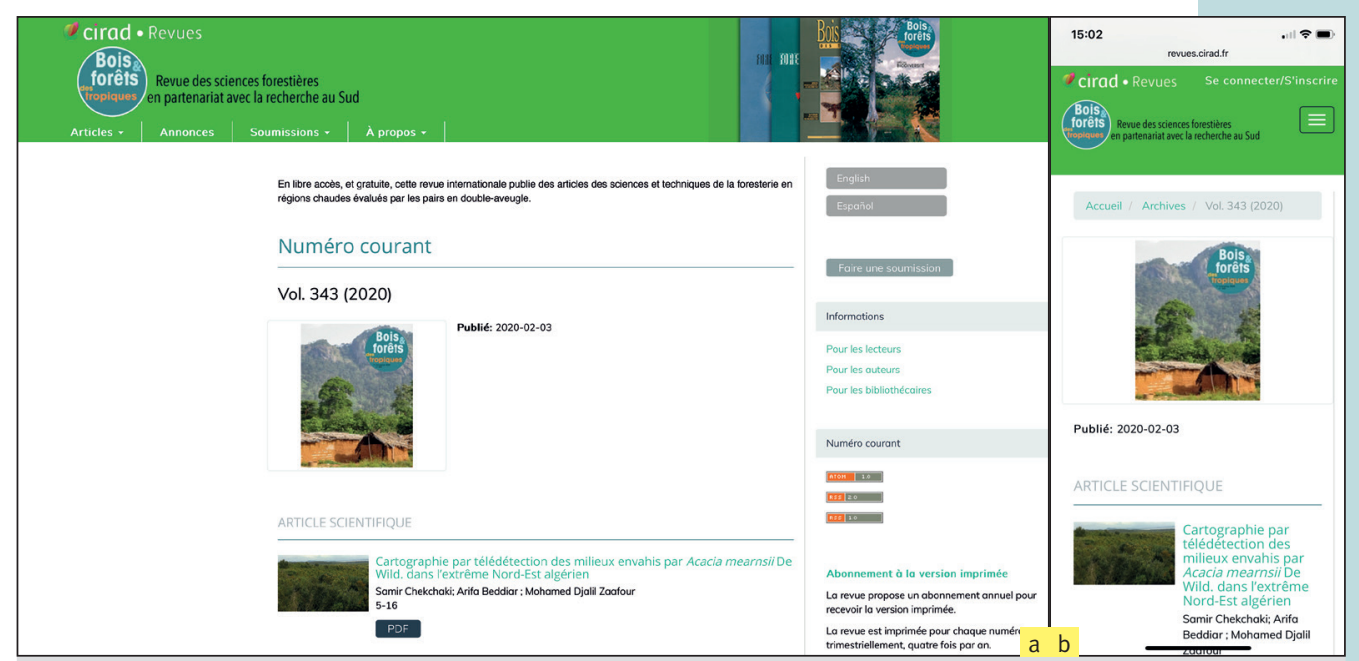

Page d'accueil du nouveau site web de la revue (a) et sa représentation sur un téléphone portable suivant une configuration responsives design (b).

Home page of the new website of the journal (a) and its representation on a smart phone in a responsive design configuration (b). 


\section{Bois et Forêts des Tropiques is changing in partnership with research from the South}

\section{Jean-François TRÉBUCHON \\ Editor-in-chief and editorial coordinator}

Since late 2018, there have been a number of changes in the way Bois et Forêts des Tropiques operates.

Taking over from Jacques Tassin, Jean-François Trébuchon is now editor-in-chief and editorial coordinator.

An editorial team has been set up, including six scientific editors: Kévin Candelier, Antoine Galiana, Laurent Gazull, Valéry Gond, Jean Gérard and Jacques Tassin. They are tasked with examining the scientific value of manuscripts submitted, supervising the double-blind review process with the help of international reviewers from North and South, and supporting authors in their final drafting once an article has been selected as publishable.

The manuscript review process takes place in three stages: (i) advice from the editorial board as to the acceptability of the submission in the light of the editorial policy and the notes to contributors, (ii) supervision, in a constructive and sympathetic manner, of the double-blind blind review process, (iii) ensuring that peer reviewer recommendations have been observed and helping authors through their final drafting before editing and publication.

The editorial board was renewed in late 2019. It now comprises some thirty international researchers accredited for their work on tropical and Mediterranean regions and affiliated to international universities or research centres. The board, as already indicated, comprises junior and senior researchers from
North and South, and observes gender parity as well as balanced representation between continents. The board members have a three-year mandate, from 2020 to 2022. They are responsible for (i) maintaining the quality of the journal's content in the light of thematic developments in environmental research on forests, trees and timber, (ii) ad hoc manuscript revising or suggesting other revisers, and, of course (iii) putting forward manuscripts, either as co-authors or on their own recommendations.

To help maintain the ethical standards inherent to research practice, our journal has acquired checker software to detect and analyze plagiarism and self-plagiarism. This is used to assist the editorial team in formulating an initial opinion on the manuscript.

In the interests of free access to publications, Bois et Forêts des Tropiques has replaced its previous CC-BY licence with the Creative Commons licence. This gives more freedom to re-use published content while protecting rights in the material of both author and journal and without breaching their copyright.

To help authors and readers to identify and access publications, Bois et Forêts des Tropiques has also upgraded its management software for website administration and on-line submissions, while maintaining the journal's indexing in international bibliographic databases.

Finally, our journal continues to be a free-access publication, distributed free of charge and financially supported by the CIRAD, in keeping with the institution's mandate to forge partnerships for the publication of research work in forestry science, and in so doing to support and cooperate with research in the South. In French or English, our journal is a springboard for both junior and senior researchers involved in the world of applied science.

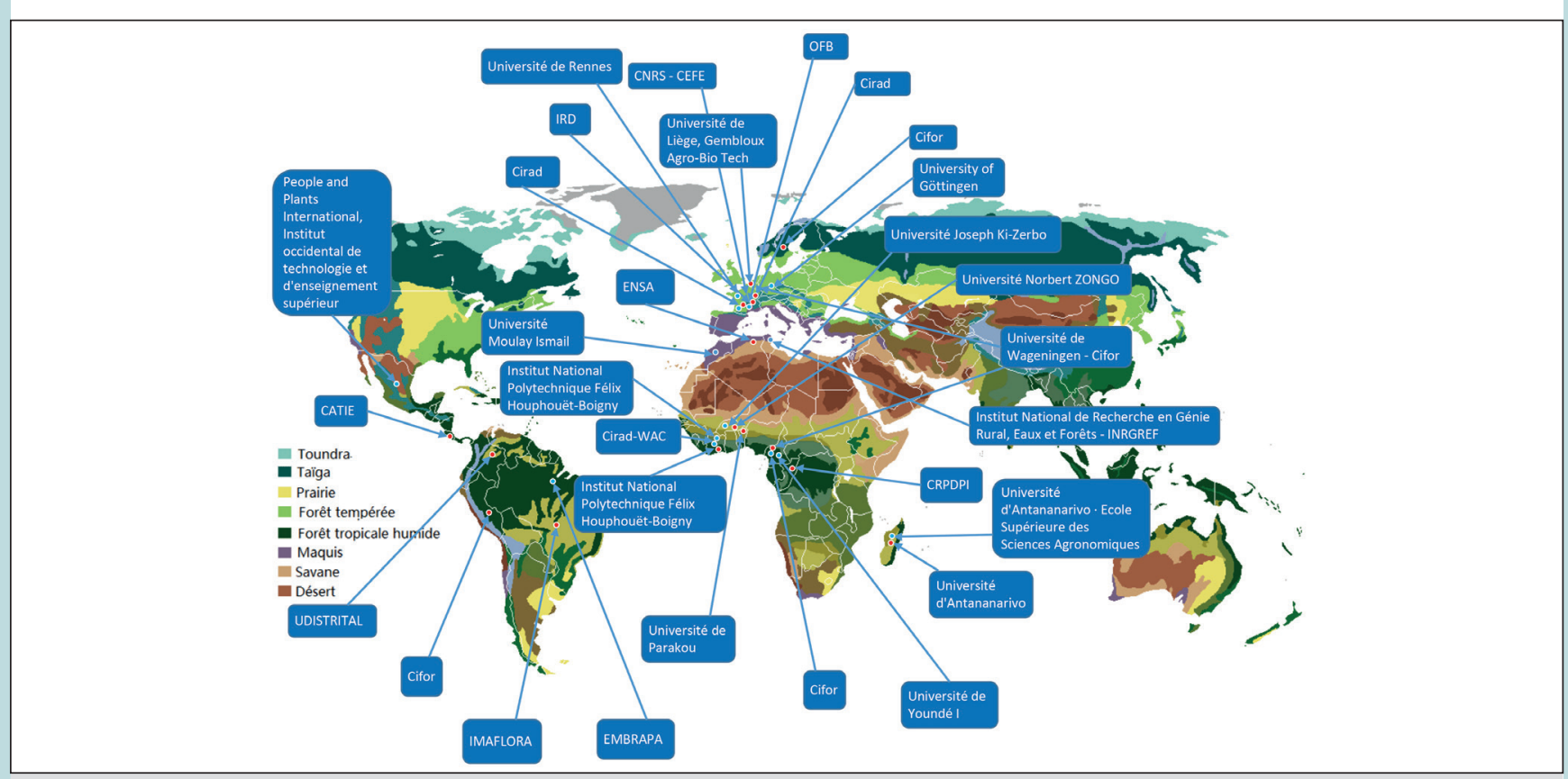

Figure 2.

Distribution cartographique des établissements contribuant à la revue par l'intermédiaire des membres du nouveau comité éditorial en place de 2020 à 2022.

Cartographic distribution of the institutions contributing to the journal through the members of the new editorial board in place from 2020 to 2022. 